\title{
PENGARUH PEMBERIAN N-ASETILSISTEIN TERHADAP EKSPRESI CASPASE-1 GLOMERULUS DAN DERAJAT KERUSAKAN GINJAL PADA MENCIT NEFRITIS LUPUS INDUKSI PRISTAN
}

\author{
ANALYSIS OF EFFECT OF N-ACETYLCYSTEINE ON CASPASE-1 EXPRESSION \\ AND DEGREE OF RENAL INJURY IN MICE MODEL OF NEPHRITIS LUPUS \\ INDUCED BY PRISTANE
}

Anindita Rachmawati, Bambang Purwanto, Diding Heri Prasetyo

Sub Bagian Ginjal-Hipertensi, Bagian Ilmu Penyakit Dalam

FK UNS / RSUD Dr. Moewardi Surakarta

Korespondensi: dr. Anindita Rachmawati SpPD, Email: dr.aninditarachmawati@gmail.com

\begin{abstract}
ABSTRAK
Lupus nefritis (LN) terkait dengan penebalan membran basal glomerulus. Pengendapan kompleks imun memicu kaskade respon inflamasi disertai aktivasi reactive oxygen species (ROS), akhirnya terjadi aktivasi caspase-1, dan caspase-1, mengaktifkan IL-1B dan IL-18 yang berlanjut terjadinya apoptosis dan nekrosis dan akhirnya terjadi kerusakan ginjal. Peningkatan ekspresi caspase-1 dapat dicegah oleh N-Asetil Sistein (NAS), yang merupakan suatu senyawa dengan efek antioksidan dan antiinflamasi. Penelitian ini bertujuan untuk mengetahui pengaruh NAS terhadap ekspresi caspase-1 dan terjadinya apoptosis dan nekrosis ginjal pada mencit model lupus nefritis. Penelitian ini merupakan penelitian eksperimental laboratoris, dengan sampel 24 ekor mencit Balb/C betina yang dibagi menjadi kelompok kontrol, $L N$, dan $L N+N A S$. Untuk membuat model LN, hewan coba diberikan injeksi $0,5 \mathrm{ml}$ pristan intraperitoneal dosis tunggal. NAS diberikan secara peroral dengan dosis $4,7 \mathrm{mg} / \mathrm{hari}$ ) selama delapan minggu. Mencit kontrol tidak diinokulasi selama penelitian. Ekspresi caspase-1 dihitung dari 100 sel makrofag yang immunoreaktif dengan teknik imunohistokimia dan kejadian apoptosis dan nekrosis dihitung dengan dengan teknik histopatologi. Hasil penelitian menunjukkan bahwa, pemberian NAS menurunkan ekspresi caspase-1 (22,8 $\pm 6,4$ vs 31,4 \pm 7,5 per 100 sel makrofag imunoreaktif; $p=0,000)$ dan menurunkan kerusakan ginjal $(6,75 \pm 2,92$ vs 9,88 $\pm 3,56 ; p=0,010)$ dibandingkan kelompok LN. NAS secara bermakna menurunkan ekspresi caspase-1 dan derajat kerusakan ginjal pada mencit model LN.
\end{abstract}

Kata Kunci: Caspase-1, Derajat Kerusakan Ginjal, Lupus Nefritis, Pristan

\section{ABSTRACT}

Lupus nephritis (LN) associated with thickening of the basal membrane of the glomerulus. The deposition of immune complexes trigger a cascade of inflammatory response accompanied the activation of reactive oxygen species (ROS), finally happened activation caspase-1, and enable the IL-1B and IL-18 to be the active form, and to be continued into occurrence of apoptosis and necrosis and eventually the kidney injury. Increased of caspase-1 expression can be prevented by N-Acetyl Cysteine (NAS), which is a compound with antioxidant and anti-inflammatory effects. This study aimed to analyze the effects of NAS on the expression of Caspase-1 and degree of renal injury in mice models of lupus nephritis. This study is an experimental research laboratory, with a sample of 24 females Balb/C mice were divided into a control group, $L N$ and $L N+N A S$. To create a model $L N$, experimental animals given intraperitoneal injection of $0.5 \mathrm{ml}$ Pristan single dose. NAS administered orally at a dose of $4.7 \mathrm{mg} /$ day for eight weeks. Control mice not inoculated during the study. Expression of Caspase-1 was calculated from 100 macrophage cells immunoreactive with immunohistochemical and degree of renal injury with histopathological techniques. One way analysis of variance (Anova) for caspase-1 expression and degree of renal injury, and $p<0.05$ were used to determine the significant differences. The provision of NAS decreased the expression of caspase-1 (22,8 $\pm 6,4$ vs 31,4 \pm 7,5 per 100 macrophage immunoreactive cells; $p=0.042)$ and degree of renal injury $(6,75 \pm 2,92$ vs 9,88 $\pm 3,56 ; p=0,010)$ compared to $L N$ group respectively. NAS significantly decrease the expression of caspase-1 and degree of renal injury in mice models $L N$.

Keywords: Caspase-1, Degree Of Renal Injury, Lupus Nephritis, Pristane 


\section{PENDAHULUAN}

Lupus Eritematosus Sistemik (LES) adalah prototipe dari penyakit inflamasi autoimun kronis yang ditandai dengan hilangnya toleransi terhadap antigen sendiri, produksi autoantibodi poliklonal, pembentukan kompleks imun, dan deposisi di bagian tubuh yang berbeda, yang mengarah pada terjadinya inflamasi yang merugikan dan cedera multi organ (Maroz and Segal, 2013; Lech and Anders, 2013). Di antara spektrum yang luas dari komplikasi LES, salah satu yang paling umum dan parah adalah lupus nefritis (LN). Lupus nefritis terjadi pada $50-70 \%$ dari pasien LES dalam lima tahun pertama diagnosis. Hal ini dapat menyebabkan kerusakan ginjal permanen dan penyakit ginjal kronis (PGK). Dimana LN menyumbang $2 \%$ dari semua PGK di Amerika Serikat (Singh et al., 2016). Keterlibatan ginjal pada awal perjalanan dari LES menjadi prediktor utama dari prognosis buruk (Maroz and Segal, 2013). Hal ini menyebabkan kematian dini dan kelangsungan hidup secara keseluruhan adalah $88 \%$ pada 10 tahun (Singh et al., 2016).

Keterlibatan ginjal pada LES merupakan manifestasi penyakit yang umum dijumpai. Inflamasi ginjal adalah salah satu manifestasi yang paling parah dari SLE dan ditandai oleh deposisi autoantibodi dan komplemen, produksi sitokin/ kemokin, aktivasi dan perekrutan sel-sel inflamasi, dan kerusakan mikrovaskuler dan parenkim di ginjal (Maroz and Segal, 2013; Lech and Anders, 2013). Pengendapan kompleks imun memicu kaskade respon inflamasi disertai aktivasi reactive oxygen species (ROS), yang memainkan peran penting dalam terjadinya kerusakan glomerulus akut dan kronis pada pasien nefritis lupus. Nefritis lupus tampak jelas secara histologis pada kebanyakan pasien dengan LES, bahkan mereka yang tidak menunjukkan manifestasi klinis penyakit ginjal (Borchers et al., 2012).

Prevalensi keterlibatan ginjal pada pasien LES di Asia menunjukkan lebih tinggi dibandingkan dengan ras Kaukasia (50-60 vs 30$38 \%$ ) dan juga sering menyebabkan penyakit ginjal yang lebih parah. Prevalensi LN di antara populasi orang Asia bervariasi. Sementara sekitar 50-60\% dari pasien LES di Asia memiliki keterlibatan ginjal, jauh lebih tinggi dari LN (70-100\%) yang telah diamati di negara-negara Asia tertentu seperti Thailand atau Sri Lanka, dengan tingkat keparahan klinis dilaporkankisaran nefrotik proteinuria
$(43,6 \%)$ dan penurunan kreatinin $(<50 \mathrm{ml} /$ menit $)$ dilaporkan 58\% dari pasien LES (Yap and Chan, 2015).

Kromatin atau nukleosom adalah antigen yang dinduksi oleh antibodi anti-dsDNA. Antibodi anti-dsDNA membentuk kompleks imun dengan nukleosom yang akan dideposisi dalam matriks mesangial akan mengaktifkan sel mesangial untuk menghasilkan sitokin dan kemokin, selanjutnya dapat menyebabkan peradangan sistemik. Produksi antibodi anti-dsDNA, pembentukan dan deposisi kompleks imun terjadi sebelum adanya infiltrasi sel imun di dalam ginjal dan berkembangnya proteinuria. Sehingga, pelepasan antigen nukleosom berperan penting dalam inisiasi LN (Lech and Anders, 2013). Kromatin atau nukleosom mengandung kompleks protein DNA dan protein pengikat histon, dan biasanya terletak di dalam inti sel. Kromatin dapat dilepaskan selama kerusakan atau kematian sel. Sumber utama nukleosom di LES diyakini berasal dari selsel mati akibat apoptosis atau nekrosis (Fenton, 2015).

Inflamasom adalah kompleks protein sitoplasma yang diaktifkan dalam merespons patogen dan danger-associated molecular patterns (DAMP). Inflamasom berfungsi sebagai kerangka untuk perekrutan dan aktivasi autoproteolitik dari caspase-1, yang membelah prekursor sitokin inaktif pro-IL-1 $\beta$ dan pro-IL-18 menjadi sitokin proinflamasi IL-1 $\beta$ dan IL-18 (Zorman et al., 2016). Aktivasi inflamasom dapat mengakibatkan piroptosis, suatu bentuk inflamasi kematian sel yang tergantung pada caspase-1. Ekspresi komponen inflamasom meningkat pada LN (Kahlenberg dan Kaplan, 2014). Caspase-1 merupakan caspase inflamasi, yang merupakan regulator respons seluler terhadap stres melalui pengaturan respon sitoprotektif, perbaikan jaringan dan kematian sel (Sun and Scott, 2016).

Pristan adalah minyak hidrokarbon alami yang dapat menginduksi peradangan kronis saat dimasukkan ke dalam rongga peritoneum. Injeksi pristan banyak digunakan sebagai model untuk pengembangan lupus dengan berbagai manifestasi yang mirip pada manusia termasuk pembentukan autoantibodi, arthritis dan glomerulonefritis berat. Selanjutnya, respon inflamasi untuk pristan menghasilkan suatu peningkatan regulasi yang kuat dari IFN tipe I melalui aktivasi TLR7 dan IRF5, memberikan kontribusi untuk fenotipe 
seperti lupus. (Kahlenberg et al., 2014).

Kerusakan radikal bebas dan stres oksidatif memainkan peran utama dalam patogenesis dan klinis gejala pada pasien LES. Radikal bebas dan reactive oxygen species (ROS) dihasilkan terusmenerus sebagai bagian dari proses metabolisme seluler. Radikal bebas akan dinonaktifkan oleh sistem pertahanan antioksidan yang terdiri dari enzim dan berbagai antioksidannonenzimatik. Stres oksidatif pada dasarnya adalah ketidakseimbangan antara produksi ROS dan mekanisme pertahanan antioksidan (Shah et al., 2014). Peningkatan produksi radikal bebas mengganggu status redoks dan dapat meningkatkan ekspresi berbagai molekul inflamasi yang mungkin menjadi penyebab penting dari inflamasi dan kerusakan jaringan. Beberapa studi menunjukkan bahwa stres oksidatif dapat menjadi faktor risiko untuk penyakit LES (Shah et al., 2014; Jafari et al., 2016). Obat-obatan yang memiliki efek seperti ROS scavenging, dan penghambatan jalur NF- $\kappa \mathrm{B}$ memiliki efek perlindungan terhadap progesifitas nefritis lupus. Jalur NF- $\mathrm{KB}$ sangat penting dalam perkembangan lupus, jalur ini mengontrol ekspresi sejumlah gen proinflamasi (Yap and La, 2015).

N-Asetil Sistein (NAS) merupakan suatu senyawa yang mengandung tiol dengan efek antioksidan dan anti inflamasi. Efek antioksidan N-Asetil Sistein dapat terjadi secara langsung melalui interaksi dengan ROS elektrofilik maupun sebagai prekusor glutation, suatu antioksidan yang dapat melindungi sel dari stres oksidatif (De Backer et al., 2013).

Meskipun penyakit ini telah dikenal selama berabad-abad, patogenesisnya masih belum jelas. Sementara terapi saat ini untuk LN terutama mengandalkan pada pemberian glukokortikoid dan imunosupresan, yang sebagian efektif dan memiliki efek samping yang cukup besar, terutama untuk penggunaan jangka panjang. Sehingga, diperlukan strategi terapi baru dan obat-obatan untuk LN. Dengan demikian, suplemen antioksidan (NAS) pada pengobatan lupus nefritis mungkin dapat mencegah/mengurangi efek kerusakan ginjal serta keparahan lupus nefritis.

\section{METODE}

Penelitian ini merupakan penelitian eksperimental, terhadap mencit sebagai hewan coba. Rancangan eksperimental tanpa adanya pengukuran awal (pretest) tetapi hanya pengukuran akhir (post test) / post-test only control group design. Tempat laboratorium Fakultas Kedokteran Universitas Sebelas Maret, waktu (Maret - Juli 2018). Subjek penelitian adalah mencit, diperoleh dari Fakultas Kedokteran Hewan Universitas Gajah Mada. Kriteria inklusi : Mencit sehat, sub spesies Mus musculus galur Balb/C, umur 6-8 minggu, berat badan 20-30 gram. Kriteria eksklusi : Mencit mati saat penelitian. Berdasar rumus didapatkan jumlah sampel minimal adalah tujuh ekor. Dalam penelitian ini digunakan delapan ekor mencit untuk setiap kelompok observasinya, sehingga telah memenuhi batas minimal sampel.

Definisi operasional : Pemberian pristan pada mencit $\mathrm{Balb} / \mathrm{C}$ menginduksi autoantibodi karakteristik lupus, N-Asetil Sistein diberikan secara peroral (sonde) dengan dosis $4,7 \mathrm{mg} / \mathrm{hari}$ (setara dengan dosis manusia $1.800 \mathrm{mg}$ ).

Ekspresi caspase-1 menggunakan pemeriksaan imunohistokimia dengan antibodi monoklonal terhadap caspase-1. Cara ukur caspase-1 dinilai secara kuantitatif, visual dengan mikroskop cahaya pembesaran 400x terhadap $100 \mathrm{sel}$, yang terlihat di makrofag yang mengekspresikan caspase-1. Kemudian dihitung jumlah sel-sel tersebut yang imunoreaktif tercat coklat perak, pada membran sel. Jumlah semua sel immunoreaktif yang ditemukan kemudian dijumlahkan dan dimasukkan sebagai data. Skala data adalah rasio.

Derajat kerusakan ginjal adalah besarnya skor kerusakan histologis sel glomerulus ginjal setelah diberi pewarnaan Hematoksilin eosin (HE). Besarnya skor kerusakan histologis dinilai dengan cara menghitung skor kerusakan yang terjadi pada sel glomerulus ginjal. Dari tiap irisan jaringan ginjal, secara acak diambil satu daerah di glomerulus ginjal. Kemudian dari tiap glomerulus tersebut dihitung jumlah sel yang mengalami kerusakan dari tiap 100 sel yang ada pada daerah glomerulus tersebut. Jika inti sel mengalami piknosis diberi skor 1, karioreksis diberi skor 2, dan kariolisis diberi skor 3 .

Data yang diperoleh akan dianalisis dengan langkah: analisis deskriptif, analisis normalitas dengan uji Shapiro-Wilk dan uji homogenitas varians dengan Levene's test, analisis komparasi. Data yang menyebar normal dan homogen, maka digunakan uji $\mathrm{F}$ Anova pada taraf kemaknaan $\alpha=0,05$ dilanjutkan dengan Least Significant Difference (LSD) post-hoc test Apabila data tidak 
normal dan homogen digunakan uji KruskalWallis, dilanjutkan uji Man Whitney.

\section{HASIL DAN PEMBAHASAN}

Penelitian ini dimaksudkan untuk mengetahui pengaruh terapi NAS terhadap ekspresi caspase-1 pada glomerulus dan tubulus interstisial dan derajat kerusakan pada ginjal mencit nefritis lupus induksi pristan. Sebelum dilakukan uji hipotesis, terlebih dahulu dijelaskan deskripsi variabel penelitian yaitu ekspresi caspase-1 dan derajat kerusakan ginjal pada kelompok kontrol, lupus nefritis, dan lupus nefritis+NAS.

Tabel 1. Deskripsi Dan Uji Normalitas Ekspresi Caspase-1 Per 100 Sel Makrofag

\begin{tabular}{llll}
\hline \multirow{2}{*}{ Kelompok } & \multicolumn{2}{c}{$\begin{array}{c}\text { Rata- } \\
\text { rata } \pm \text { SD }\end{array}$} & \multicolumn{2}{c}{ Uji Normalitas } \\
\cline { 3 - 4 } & $9,9 \pm 6,8$ & Stat-SW & Sig \\
\hline Kontrol & 31,955 & 0,75 \\
Lupus nefritis & $31,4,5$ & 0,961 & 0,82 \\
Lupus nefritis+NAS & $22,8 \pm 6,4$ & 0,985 & 0,98 \\
\hline
\end{tabular}

Sumber: Data Primer 2018, diolah.

Berdasarkan deskripsi variabel ekspresi caspase-1 di atas, terlihat bahwa mencit yang diinduksi pristan (mencit model lupus nefritis) memiliki rata-rata ekspresi caspase-1 lebih tinggi dibandingkan pada kelompok kontrol. Pemberian NAS mampu menurunkan ekspresi caspase-1. Perbedaan rata-rata ekspresi caspase-1 antar kelompok sampel itu dapat digambarkan sebagai berikut:

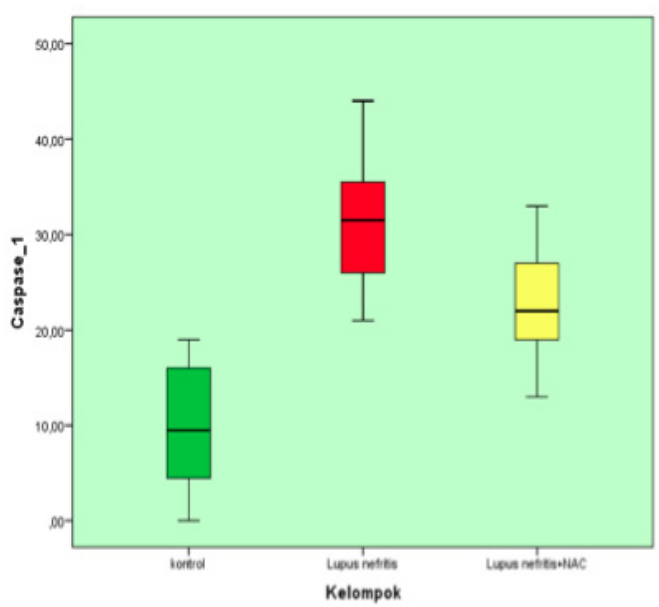

Gambar 1. Perbandingan nilai rata-rata ekspresi caspase-1 pere 100 sel makrofag antar kelompok sampel
Deskripsi rinci nilai rata-rata dan standar deviasi serta hasil uji normalitas data masingmasing kelompok untuk variabel tingkat kerusakan ginjal adalah sebagai berikut:

Tabel 2. Deskripsi Dan Uji Normalitas Variabel Tingkat Kerusakan Ginjal

\begin{tabular}{|c|c|c|c|}
\hline \multirow[t]{2}{*}{ Kelompok } & \multirow{2}{*}{$\begin{array}{c}\text { Rata- } \\
\operatorname{rata} \pm S D\end{array}$} & \multicolumn{2}{|c|}{ Uji Normalitas } \\
\hline & & Stat-SW & Sig \\
\hline Kontrol & $5,25 \pm 1,49$ & 0,920 & \\
\hline Lupus nefritis & $9,88 \pm 3,56$ & 0,952 & \\
\hline Lupus nefritis+NAS & $6,75 \pm 2,92$ & 0,973 & \\
\hline
\end{tabular}

Sumber: Data Primer 2018, diolah.

Berdasarkan deskripsi variabel tingkat kerusakan ginjal di atas, pemberian NAS menurunkan ratarata tingkat kerusakan ginjal dibandingkan pada kelompok lupus nefritis. Perbedaan rata-rata tingkat kerusakan ginjal antar kelompok sampel itu dapat digambarkan sebagai berikut:

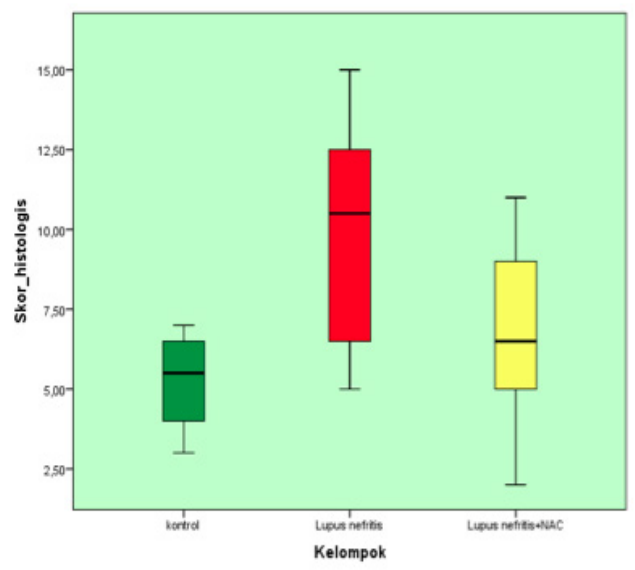

Gambar 2. Perbandingan nilai rata-rata tingkat kerusakan ginjal antar kelompok sampel

Dengan demikian distribusi data variabel ekspresi caspase-1 dan tingkat kerusakan ginjal sudah dideskripsikan secara ringkas dan sudah dilakukan pengujian normalitas data terhadap variabel tersebut dan hasilnya semua distribusi data kedua variabel penelitian itu berdistribusi normal.

Langkah pertama menguji variasi atau beda $\mathrm{k}$ rata-rata berdasarkan kelompok sampel untuk variabel caspase-1. Distribusi data variabel caspase-1 semua kelompok sampel berdistribusi normal, maka pengujian variasi atau beda 3 ratarata itu menggunakan ANOVA atau uji F. Hasil 
pengujian ANOVA untuk variabel caspase-1 adalah sebagai berikut:

Tabel 3. Perbedaan Rata-Rata Ekspresi Caspase-1 Per 100 Sel Makrofag Dalam Kelompok Sampel

\begin{tabular}{|c|c|c|c|c|c|}
\hline \multicolumn{2}{|c|}{ Kontrol } & \multicolumn{2}{|c|}{ Lupus Nefritis } & \multicolumn{2}{|c|}{$\begin{array}{c}\text { Lupus } \\
\text { Nefritis+NAS }\end{array}$} \\
\hline $\begin{array}{l}\text { Rata- } \\
\text { rata }\end{array}$ & Std & $\begin{array}{l}\text { Rata- } \\
\text { rata }\end{array}$ & Std & $\begin{array}{c}\text { Rata- } \\
\text { rata }\end{array}$ & Std \\
\hline 9,9 & 6,8 & 31,4 & 7,5 & 23,8 & 6,4 \\
\hline \multicolumn{2}{|c|}{ Nilai $F=19,741$} & \multicolumn{2}{|c|}{$\begin{array}{c}\text { Signifikansi }= \\
0,000^{* *}\end{array}$} & \multicolumn{2}{|c|}{ Signifikan } \\
\hline
\end{tabular}

Sumber: Data Primer 2018, diolah.

Keterangan: ${ }^{* *}$ ) signifikan pada derajat signifikansi 1 persen

Hasil analisis variasi atau beda 3 rata-rata di atas menunjukkan bahwa perbedaan 3 rata-rata variabel caspase-1 tersebut menghasilkan nilai $\mathrm{F}$ hitung $=19,741$ dengan tingkat signifikansi sebesar 0,000 yang berarti beda 3 rata-rata itu signifikan atau meyakinkan dengan derajat signifikansi $\mathrm{p}<0,01$. Hal itu berarti beda rata-rata variabel caspase-1 pada kelompok kontrol, lupus nefritis, dan lupus nefritis+NAS benar-benar berbeda secara meyakinkan. Jika dibandingkan dengan rata-rata caspase-1 pada kelompok kontrol, kelompok lupus nefritis memiliki kecenderungan rata-rata caspase-1 lebih tinggi (meningkat), kemudian rata-rata caspase-1 pada kelompok lupus nefritis+NAS memiliki rata-rata lebih rendah dibandingkan kelompok lupus nefritis atau berarti ekspresi caspase-1 itu dapat ditekan dengan pemberian NAS.

Hasil penelusuran beda dua rata-rata variabel caspase-1 antar kelompok sampel dapat dijelaskan dengan tabel sebagai berikut:

Tabel 4. Perbedaan Rata-Rata Ekspresi Caspase-1 Per 100 Sel Makrofag Antar Kelompok Sampel

\begin{tabular}{llll}
\hline \multicolumn{2}{c}{ Kelompok } & \multicolumn{1}{c}{$\begin{array}{c}\text { Beda Rata- } \\
\text { rata }\end{array}$} & Signifikansi \\
\hline $\begin{array}{l}\text { Kontrol vs lupus } \\
\text { nefritis }\end{array}$ & $-21,50$ & 0,000 \\
$\begin{array}{l}\text { Lupus nefritis vs } \\
\text { lupus nefritis+NAS } \\
\text { Kontrol vs lupus }\end{array}$ & $0,021^{*}$ \\
nefritis+NAS & 0,001 \\
\hline & \multicolumn{2}{c}{ Sumber: Data Primer 2018, diolah. } \\
Keterangan: *) signifikan pada derajat signifikansi 5 persen
\end{tabular}

Hasil analisis beda 2 rata-rata sampel independen menggunakan penelusuran Post Hoc Test LSD diatas menunjukkan bahwa uji terhadap variabel caspase-1 antara kelompok Kontrol dan lupus nefritis signifikan pada derajat signifikansi sebesar $0,000(\mathrm{p}<0,001)$. Hal itu dapat dikatakatan bahwa pada mencit kelompok lupus nefritis mempunyai rata-rata ekspresi caspase-1 lebih tinggi (meningkat) secara meyakinkan dibandingkan kelompok kontrol. Setelah diberikan terapi NAS maka rata-rata ekspresi caspase-1 lebih rendah (mengalami penurunan) dibandingkan pada kelompok lupus nefritis dengan tingkat signifikansi sebesar 0,021 ( $p<$ $0,05)$. Dengan demikian hipotesis pertama yang menyatakan bahwa: "Pemberian $N$-asetilsistein menurunkan ekspresi caspase-1 pada mencit lupus nefritis induksi pristan" benar-benar dapat terbukti secara meyakinkan. Pemberian NAS mampu menurunkan ekspresi caspase-1.

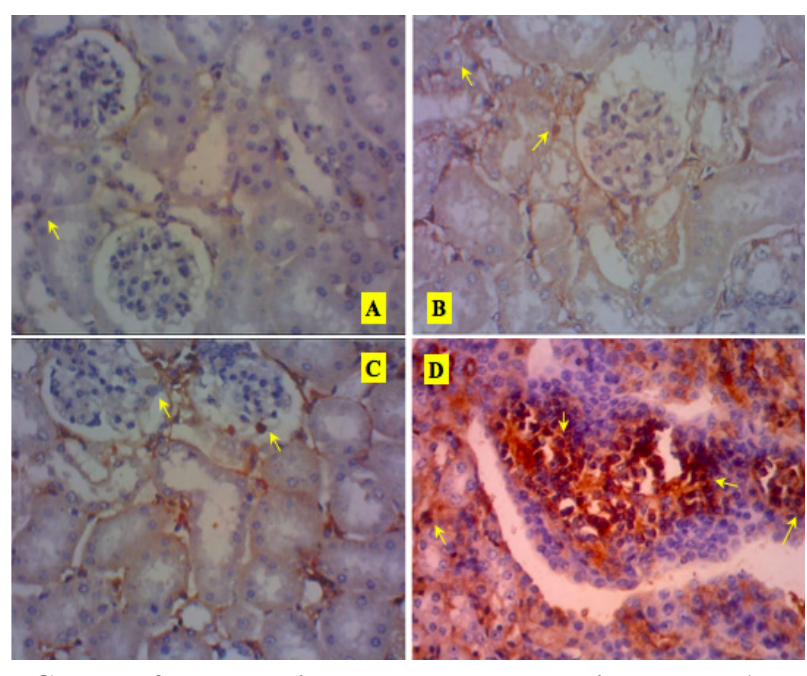

Gambar 3. Perbandingan gambaran protein caspase-1 yang diekspresikan sel makrofag masing-masing kelompok

Langkah kedua menguji variasi atau beda $\mathrm{k}$ rata-rata berdasarkan kelompok sampel untuk variabel tingkat kerusakan ginjal. Distribusi data tingkat kerusakan ginjal secara keseluruhan masing-masing kelompok data berdistribusi normal, maka pengujian variasi atau beda 3 rata-rata itu menggunakan ANOVA atau uji $\mathrm{F}$. Hasil pengujian ANOVA untuk variabel tingkat kerusakan ginjal adalah sebagai berikut: 
Tabel 5. Perbedaan Rata-Rata Tingkat Kerusakan Ginjal Menurut Kelompok Sampel

\begin{tabular}{|c|c|c|c|c|c|}
\hline \multicolumn{2}{|c|}{ Kontrol } & \multicolumn{2}{|c|}{ Lupus Nefritis } & \multicolumn{2}{|c|}{$\begin{array}{c}\text { Lupus } \\
\text { Nefritis+NAS }\end{array}$} \\
\hline $\begin{array}{c}\text { Rata- } \\
\text { rata }\end{array}$ & Std & $\begin{array}{l}\text { Rata- } \\
\text { rata }\end{array}$ & Std & $\begin{array}{l}\text { Rata- } \\
\text { rata }\end{array}$ & Std \\
\hline 5,25 & 1,49 & 9,88 & 3,56 & 6,75 & 2,92 \\
\hline \multicolumn{2}{|c|}{ Nilai $F=5,708$} & \multicolumn{2}{|c|}{$\begin{array}{c}\text { Signifikansi }= \\
0,010^{*}\end{array}$} & \multicolumn{2}{|c|}{ Signifikan } \\
\hline
\end{tabular}

Sumber: Data Primer 2018, diolah.

Keterangan: *) signifikan pada derajat signifikansi 5 persen

Hasil analisis variasi atau beda 3 rata-rata di atas menunjukkan bahwa perbedaan 3 ratarata variabel tingkat kerusakan ginjal tersebut menghasilkan nilai $\mathrm{F}$ hitung $=5,708$ dengan tingkat signifikansi sebesar 0,010 yang berarti beda 3 ratarata itu signifikan atau meyakinkan dengan derajat signifikansi $\mathrm{p}<0,05$. Hal itu berarti beda rata-rata variabel tingkat kerusakan ginjal pada kelompok kontrol, lupus nefritis, dan lupus nefritis+NAS benar-benar berbeda secara meyakinkan. Jika dibandingkan dengan rata-rata tingkat kerusakan ginjal pada kelompok kontrol, kelompok lupus nefritis memiliki kecenderungan rata-rata tingkat kerusakan ginjal lebih tinggi (meningkat), kemudian rata-rata tingkat kerusakan ginjal pada kelompok lupus nefritis+NAS memiliki rata-rata lebih rendah (menurun) dibandingkan kelompok lupus nefritis atau berarti tingkat kerusakan ginjal itu dapat diturunkan dengan pemberian NAS.

Gambaran secara histologis tingkat kerusakan ginjal dengan pewarnaan Hematoksilin eozin (HE) untuk kelompok mencit normal (kontrol) adalah sebagai berikut:
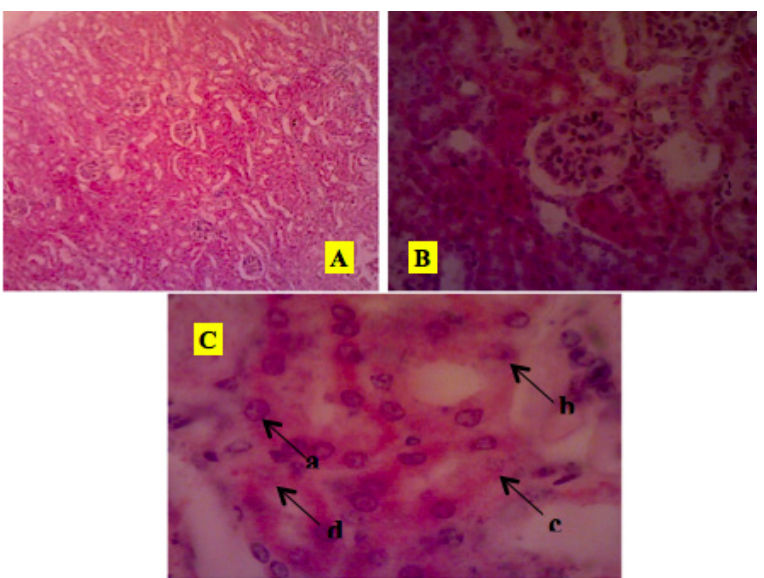

Gambar 4. Gambaran histologis tingkat kerusakan ginjal kelompok kontrol
Gambaran secara histologis tingkat kerusakan ginjal dengan pewarnaan HE untuk kelompok mencit yang diinduksi pristan adalah sebagai berikut:
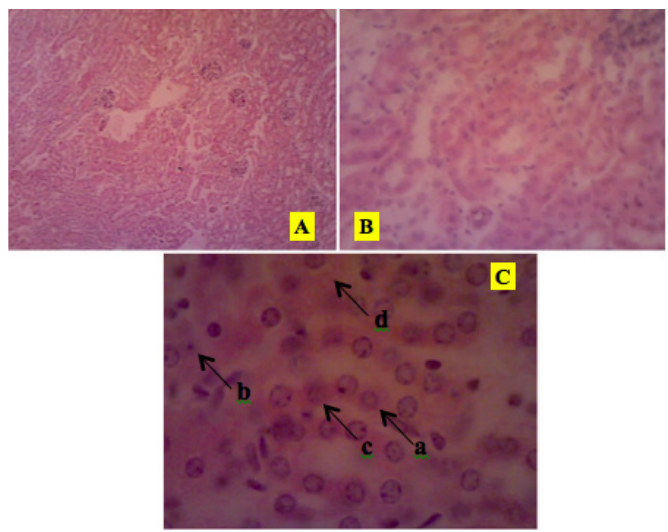

Gambar 5. Gambaran histologis tingkat kerusakan ginjal kelompok Lupus nefritis

Gambaran secara histologis tingkat kerusakan ginjal dengan pewarnaan HE untuk kelompok mencit induksi pristan yang diberikan NAS adalah sebagai berikut:
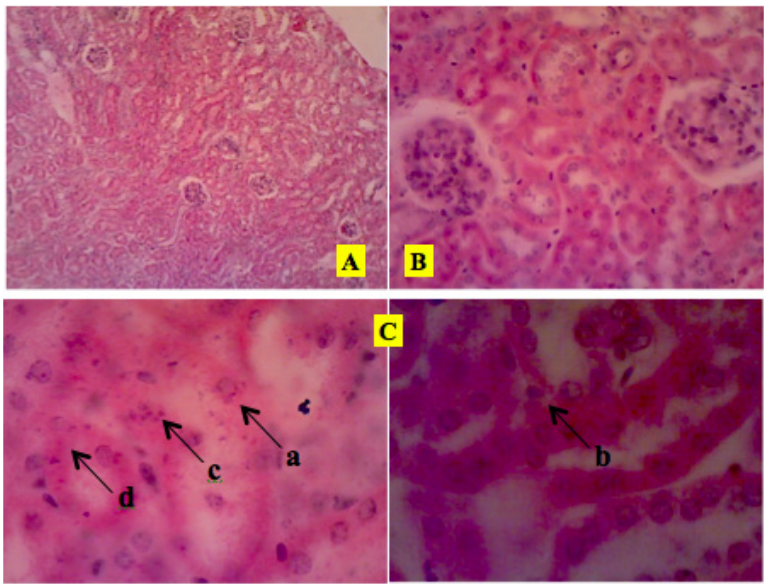

Gambar 6. Gambaran histologis tingkat kerusakan ginjal kelompok Lupus nefritis+NSA

Hasil penelusuran beda dua rata-rata variabel tingkat kerusakan ginjal antar kelompok sampel dapat dijelaskan dengan tabel sebagai berikut: 
Tabel 6. Perbedaan Rata-Rata Tingkat Kerusakan Ginjal Antar Kelompok Sampel

\begin{tabular}{ccc}
\hline Kelompok & $\begin{array}{c}\text { Beda Rata- } \\
\text { rata }\end{array}$ & Signifikansi \\
\hline $\begin{array}{c}\text { Kontrol vs lupus } \\
\text { nefritis }\end{array}$ & $-4,63$ & $0,003^{*}$ \\
$\begin{array}{c}\text { Lupus nefritis vs lupus } \\
\text { nefritis+NAS }\end{array}$ & 3,13 & $0,036^{*}$ \\
$\begin{array}{c}\text { Kontrol vs lupus } \\
\text { nefritis +NAS }\end{array}$ & $-1,50$ & 0,295 \\
\hline $\begin{array}{c}\text { Sumber: Data Primer 2018, diolah. } \\
\text { Keterangan: } * \text { ) signifikan pada derajat signifikansi } 5 \text { persen. } \\
* *) \text { signifikan pada derajat 1 persen. }\end{array}$
\end{tabular}

Hasil analisis beda 2 rata-rata sampel independen menggunakan penelusuran Post Hoc Test LSD diatas menunjukkan bahwa uji terhadap variabel tingkat kerusakan ginjal antara kelompok Kontrol dan lupus nefritis signifikan pada derajat signifikansi sebesar 0,003 (p < 0,01). Hal itu dapat dikatakatan bahwa pada mencit kelompok lupus nefritis rata-rata tingkat kerusakan ginjal lebih tinggi (meningkat) secara meyakinkan dibandingkan kelompok kontrol. Setelah diberikan terapi NAS maka rata-rata tingkat kerusakan ginjal lebih rendah (mengalami penurunan) dibandingkan pada kelompok lupus nefritis dengan tingkat signifikansi sebesar 0,036 $(\mathrm{p}<0,05)$. Dengan demikian hipotesis kedua yang menyatakan bahwa: "Pemberian $N$-asetilsistein menurunkan tingkat kerusakan ginjal pada mencit lupus nefritis induksi pristan" benar-benar dapat terbukti secara meyakinkan. Pemberian NAS mampu menurunkan tingkat kerusakan ginjal.

Penelitian ini didapatkan suatu proses sesuai dalam tahapan proses penyakit yang dikenal dengan initial stage (Incubation period/ Sub clinical) (Purwanto, 2010). Dimana berdasarkan prinsip ontologi, injeksi pristan pada mencit BALB/c secara intraperitoneal dapat mengembangkan respons inflamasi lokal dan menginduksi produksi autoantibodi yang bermanifestasi klinis SLE. Mencit yang diinjeksi pristan memperlihatkan manifestasi klinis dari lupus, termasuk artritis, glomerulonefritis dan kapilaritis paru. Glomerulonefritis yang terjadi sebagai akibat dari adanya proses deposit kompleks imun yaitu IgG dan komplemen di glomerulus, proliferasi sel dan proteinuria (Reeves et al., 2009) yang pada akhirnya terjadi kerusakan ginjal. Terjadinya kerusakan pada jaringan ginjal pada penelitian ini dapat dideteksi pada tingkat molekuler yaitu perubahan ekspresi caspase-1 pada makrofag glomerulus dengan metode imunohistokimia dan tingkat seluler yaitu dari terjadinya kerusakan pada glomerulus ginjal yang dilakukan pemeriksaan histopatologi.

Injeksi pristan i.p. akan mengaktivasi $\mathrm{NF \kappa} \beta$ dan p38 MAPK sehingga terjadi peningkatan produksi TGF- $\beta$. TGF- $\beta$ akan merangsang sel target, yaitu sel fibroblas, sel mesangial, podosit, sel tubulus dan sel endotel. Aktivasi sel-sel target ini akan memicu terbentuknya ECM. Sel fibroblas akan mengekspresikan kolagen tipe-I dan akhirnya menyebabkan terjadinya fibrosis interstisial pada ginjal (Purwanto, 2010; Loeffler and Wolf, 2013). Proses ini sesuai dengan tahap emergence stage dalam tahapan proses penyakit (Purwanto, 2010).

Setelah injeksi pristan secara intraperitoneal, maka produksi caspase-1 meningkat secara signifikan utamanya diproduksi oleh makrofag. Selain itu juga akan merangsang TNF $\alpha$ lokal, sehingga akan menyebabkan endotel mengekspresikan e-selektin yang diperlukan untuk mengikat PMN. PMN kemudian akan mengekspresikan MMP-9. MMP-9 selanjutnya mendegradasi kolagen yang diekspresikan oleh sel fibroblas. Dalam keadaan normal sesuai dengan hukum homeostasis, terjadi keseimbangan pengaruh TGF- $\beta 1$ dan MMP-9. TGF- $\beta 1$ juga menghambat ekspresi MMP-9 yang diekspresikan oleh PMN. Pada penelitian ini injeksi pristan diharapkan akan menyebabkan TGF- $\beta 1$ lebih dominan daripada MMP-9, sehingga terjadi interstitial fibrosis. IL-1 $\beta$ akan merangsang endotel untuk mengekspresikan ICAM, selanjutnya ICAM akan mengikat monosit kemudian monosit akan masuk ke jaringan dan akan berubah menjadi makrofag.

Makrofag yang bertambah banyak akan menyebabkan meningkatnya proses ekspresi sitokin dan caspase-1 yang berakibat pada bertambah beratnya fibrosis dan kerusakan ginjal (Purwanto, 2010). Tahap ini sesuai dengan active stage.

Pemberian NAS pada mencit lupus nefritis pada penelitian ini, NAS berperan sebagai anti ROS, sehingga kerusakan sel (debris) berkurang, akibatnya rangsangan terhadap makrofag lewat TLR-4, TLR-7 dan TLR-9 berkurang pula. Akibatnya ekspresi caspase-1 oleh makrofag juga berkurang, kondisi tersebut akan berperan dalam memperbaiki keadaan imbalance tersebut. 
Berdasarkan pendekatan prinsip epistomologi, penelitian ini ekspresi caspase-1 di makrofag ginjal pada kelompok mencit yang diinduksi pristan sebagai agen nefrotoksik terlihat lebih tinggi daripada mencit normal sebagai kontrol. Peningkatan ekspresi caspase-1 terjadi karena pemberian pristan akan menyebabkan (a) stimulasi mediator inflamasi, (b) peningkatan produksi autoantibodi, (c) peningkatan deposisi kompleks imun di glomerulus, (d) peningkatan TGF- $\beta 1$, (e) meningkatnya imunogenisitas dan (f) apoptosis yang meningkat (Reeves et al., 2009).

Pemberian kombinasi NAS pada model lupus nefritis dapat menurunkan ekspresi caspase-1. NAS mengandung sulfur-hidril berperan sebagai antioksidan poten. Kandungan sulfur-hidril endogen pada NAS berperan penting dalam penyangga metabolik yang digunakan sel untuk melawan kekuatan oksidatif stres. Sulfurhidril tersebut bertindak sebagai prekusor sintesis glutation yang akan menghasilkan detoksifikasi substrat asing (Li et al., 2015).

Kematian sel nekrotik ditandai dengan pembengkakan sitoplasma dan organel, diikuti dengan hilangnya integritas membran sel dan pelepasan isi sel ke dalam ruang ekstraseluler sekitarnya, yang menghasilkan respons inflamasi jaringan. Keadaan ini akan menginduksi terjadinya Aktivasi $N F \kappa \beta$ juga, yang akan meningkatkan produksi faktor pertumbuhan termasuk TGF- $\beta 1$. TGF- $\beta 1$ akan merangsang sel target, yaitu sel fibroblas, sel mesangial, podosit, sel tubulus dan sel endotel. Aktivasi sel-sel target ini akan memicu terbentuknya ECM. Sel fibroblas akan mengekspresikan kolagen tipe-I dan akhirnya menyebabkan terjadinya fibrosis interstisial pada ginjal. Sedangkan sel mesangial yang terletak pada glomerulus akan mengekspresikan kolagen tipe-IV, selanjutnya akan menyebabkan terjadinya glomerulosklerosis (Purwanto, 2010; Loeffler and Wolf, 2013). Aktivasi TGF- $\beta 1$ pada sel podosit, menyebabkan produksi ECM, abnormalitas prosesus podosit, apoptosis sel, dan transisi sel epitel menjadi mesensimal, selanjutnya menyebabkan terjadinya glomerulosklerosis. TGF- $\beta 1$ juga akan mengaktivasi sel endotel untuk memproduksi ECM, proliferasi sel, apoptosis sel dan transisi sel endotel menjadi mesensimal, selanjutnya menyebabkan terjadinya glomerulosklerosis dan fibrosis interstisial pada ginjal. Aktivasi TGF- $\beta 1$ pada sel tubulus ginjal, menyebabkan produksi ECM, proliferasi sel, apoptosis sel dan transisi sel epitel menjadi mesensimal, selanjutnya menyebabkan terjadinya fibrosis interstisial pada ginjal. Produksi TNF- $\alpha$, juga akan menyebabkan terjadinya apoptosis yang berlebihan dari sel mesangial, podosit, sel tibulus dan sel endotel (Loeffler and Wolf, 2013).

Secara keseluruhan, hasil penelitian ini menunjukkan efek nefroprotektif dari NAC. Pada penelitian ini efek nefroprotektifnya terlihat baik secara molekuler (ekspresi caspase-1) maupun seluler (tingkat kerusakan sel ginjal). Hasil ini diperkuat dengan penelitian Rababa'h et al (2018), bahwa pemberian NAC mampu memproteksi ginjal dari nefrotoksisitas melalui efek antioksidannya,

Berdasarkan prinsip axiologi, secara keseluruhan manfaat hasil penelitian ini adalah kombinasi lupus nefritis+NAS dapat mencegah/ mengurangi efek nefrotoksik pada ginjal. NAS merupakan suatu senyawa yang mengandung tiol dengan efek antioksidan dan antiinflamasi. Efek antioksidan NAS dapat terjadi secara langsung melalui interaksi dengan ROS elektrofilik maupun sebagai prekusor glutation, suatu antioksidan yang dapat melindungi sel dari stres oksidatif (De Backer et al., 2013). Stres oksidatif terjadi ketika produksi ROS berlebihan melebihi kapasitas metabolisme dari sistem pertahanan antioksidan, sehingga mengakibatkan kerusakan jaringan ginjal. Terapi NAS akan menghambat ekspresi dan aktivitas enzim antioksidan seperti SOD, katalase dan glutation peroksidase. Dengan demikian, suplemen NAS pada lupus nefritis dapat mengurangi efek nefrotoksik pada ginjal, melalui penurunan ekspresi csapase-1 dan derajat kerusakan ginjal.

\section{SIMPULAN}

N-Asetil Sistein terbukti menurunkan ekspresi caspase-1 dan menurunkan derajat kerusakan ginjal pada mencit lupus nefritis induksi pristan. 


\section{DAFTAR PUSTAKA}

Bambang, P. 2010. Kajian ekspresi tgf- $\beta 1$, mmp-9, kolagen tipe-I, kolagen tipe-IV, glomerulosklerosis, interstisial fibrosis, albuminuri pada kejadian nefrotoksik doxorubicin dan nefroprotektif pentoxifylin dengan hewan coba mencit galur swiss jantan. Disertasi. Program Pascasarjana. Universitas Airlangga. Surabaya.

Borchers, A.T, Leibushor, N., Naguwa, S.M., Cheema, G.S., Shoenfeld, Y., Gershwin, M.E.2012. Lupus nephritis: a critical review. Autoimmun Rev. 12(2):174-94.

De Backer, J., Vos, W., Van Holsbeke, C., Vinchurkar, S., Claes, R., Parizel, P.M., De Backer, W. 2013. Effect of high-dose $\mathrm{N}$-acetylcysteine on airway geometry, inflammation, and oxidative stress in COPD patients. Int J Chron Obstruct Pulmon Dis. 8:569-79.

Fenton, K. 2015. The effect of cell death in the initiation of lupus nephritis.Clin Exp Immunol.179(1):11-6.

Jafari, S.M., Salimi, S., Nakhaee, A., Kalani, H., Tavallaie, S., Farajian-Mashhadi, F., Zakeri, Z., Sandoughi, M. 2016. Prooxidant-Antioxidant Balance in Patients with Systemic Lupus Erythematosus and Its Relationship with Clinical and Laboratory Findings. Autoimmune Dis. 2016:4343514. doi: 10.1155/2016/4343514.

Kahlenberg, J.M. and Kaplan, M.J. 2014. The inflammasome and lupus: another innate immune mechanism contributing to disease pathogenesis?Curr Opin Rheumatol. 26(5):475-81.

Kahlenberg, J.M., Yalavarthi, S., Zhao, W., Hodgin, J.B., Reed, T.J., Tsuji, N.M., Kaplan, M.J. 2014. An essential role of caspase 1 in the induction of murine lupus and its associated vascular damage. Arthritis Rheumatol. 66(1):152-62.

Lech, M. and Anders, H.J. 2013. The pathogenesis of lupus nephritis. J Am Soc Nephrol. 24(9):135766.

Li, M., Gao, W., Ma, J., Zhu, Y., Li, X. 2015.Early-stage lupus nephritis treated with N-acetylcysteine: A report of two cases. Exp Ther Med. 10(2):689-692.

Loeffler, I. and Wolf, G. 2013. Transforming growth factor- $\beta$ and the progressionof renal disease. Nephrol Dial Transplant 0: 1-9.

Maroz, N. and Segal, M.S. 2013. Lupus nephritis and end-stage kidney disease. Am. J. Med. Sci. 346:319-323.

Rababa'h, A.M., Hijjawi, T.B., Alzoubi, K.H., Al Demour, S., Ababneh, M.A. The Nephroprotective Effect of N-Acetyl-L-Cysteine and Atorvastatin against Imipenem induced Nephrotoxicity. Curr Mol Pharmacol. 2018;11(2):155-161.

Reeves, W.H., Lee, P.Y., Weinstein, J.S., Satoh, M., Lu, L. 2009. Induction of autoimmunity by pristane and other naturally occurring hydrocarbons. Trends Immunol 30(9):455-64.

Shah, D., Mahajan, N., Sah, S., Nath, S.K., Paudyal, B. 2014. Oxidative stress and its biomarkers in systemic lupus erythematosus. J Biomed Sci. 21():23.

Singh, J.A., Hossain, A., Kotb, A., Oliveira, A., Mudano, A.S., Grossman, J., Winthrop, K., Wells, G.A. 2016. Treatments for Lupus Nephritis: A Systematic Review and Network Metaanalysis. $J$ Rheumatol. 43(10):1801-1815.

Sun, Q. and Scott, M.J. 2016. Caspase-1 as a multifunctional inflammatory mediator: noncytokine maturation roles.J Leukoc Biol. pii: jlb.3MR0516-224R. PMID:27450556.

Yap, D.Y. and Chan, T.M. 2015. Lupus Nephritis in Asia: Clinical Features and Management. Kidney Dis (Basel). 1(2):100-9.. 
Yap, D.Y.H. and La, K.N. 2015. Pathogenesis of Renal Disease in Systemic Lupus ErythematosusThe Role of Autoantibodies and Lymphocytes Subset Abnormalities. Int J Mol Sci. 16(4): 7917-7931.

Zorman, J., Susjan, P., and Hafner-Bratkovic, I. 2016. Shikonin Suppresses NLRP3 and AIM2 Inflammasomes by Direct Inhibition of Caspase-1. PLoS One. 11(7): e0159826. 